\title{
Quality Assurance Report on Exotic Plants: \\ EMAP Western Pilot Field Sites in \\ Montana
}

Prepared for:

The United States Environmental Protection Agency

200 S. W. 35th St.

Corvallis, Oregon

97333

Prepared by:

Catherine Jean

November 2001

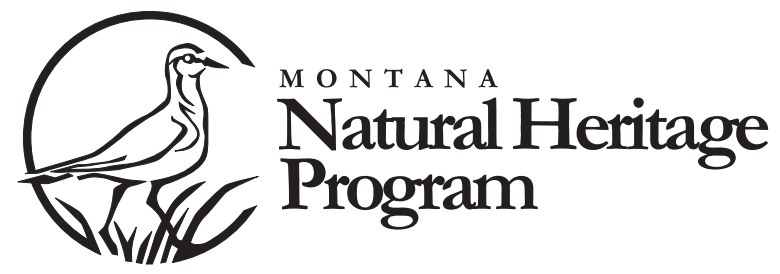




\title{
Quality Assurance Report on Exotic Plants:
}

\section{EMAP Western Pilot Field Sites in Montana}

\author{
(c) 2001 Montana Natural Heritage Program
}

Montana State Library P.O. Box 201800 Helena, Montana 59620-1800 406-444-3009

purchase order \#

0B0368NTNA change \#1

This document should be cited as:

Jean, C. 2001. Quality Assurance Report on Exotic Plants: EMAPWestern Pilot Field Sites in Montana Report to the United States Environmental Protection Agency. Montana Natural Heritage Program, Helena, MT. 4 pp. plus appendices. 


\section{TABLE OF CONTENTS}

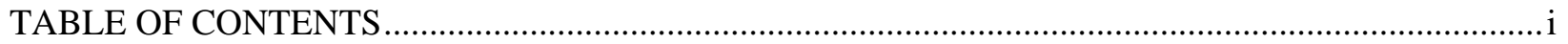

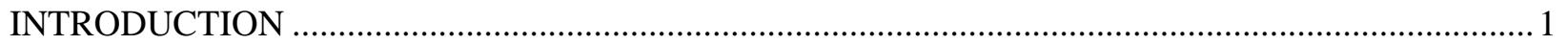

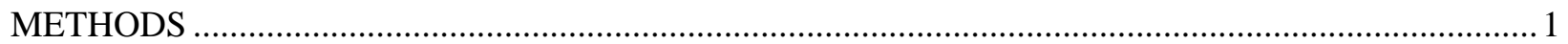

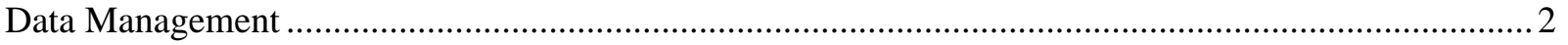

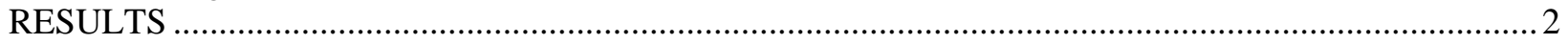

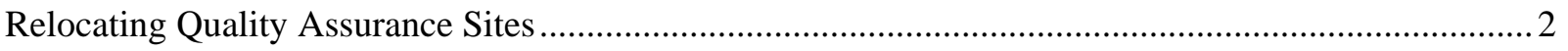

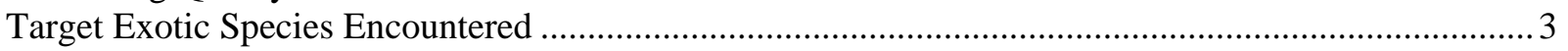

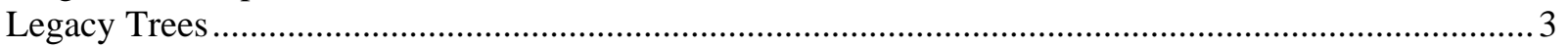

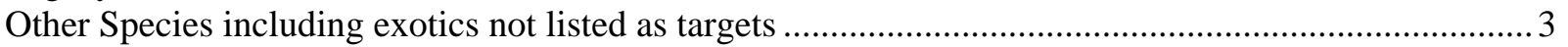

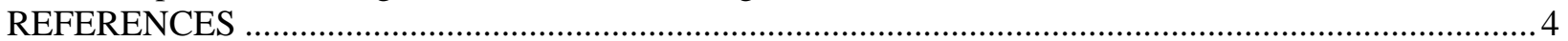




\section{INTRODUCTION}

This is an analysis and report on the EMAP Western Pilot Quality Assurance (QA) inventory conducted by the Montana Natural Heritage Program (MTNHP) during the 2001 field season. The purpose of this work is to assist in the evaluation of the quality and value of exotic plant and legacy tree information collected by Montana Department of Environmental Quality (MTDEQ). Six wadeable streams inventoried by MTDEQ in 2001 and included in this report are Fred Burr Creek, Hungry Horse Creek, Little Boulder Creek, Moose Creek, South Fork Little Joe Creek, and an un-named tributary of the Tenderfoot River.

\section{METHODS}

The quality assurance work was completed during the same field season that MTDEQ completed their inventory. After the initial inventory was done, Rose Sade at MTDEQ contacted MTNHP with the exact GPS location for the plot or site center. With this information plotted on a 1:24,000 quad map and a GPS unit, MTNHP staff was able to relocate the exact plot center. The location was confirmed by flagging left by MTDEQ.

Two ecologists for MTNHP conducted the quality assurance inventory; Catherine Jean, Ecology Program Manger, has a MS in Forest Ecology from Utah State University and has worked professionally as a botanist and ecologist for 11 years; Steve Cooper has a PhD in Botany from Washington State University and has worked professionally as an ecologist for 26 years. As professional ecologists, Catherine and Steve spend most of each summer identifying plants while conducting ecological surveys. Steve is very familiar with local flora, having worked in Montana for 18 years; Catherine is less familiar, having worked in Montana for three field seasons. Steve was able to identify all plants to species, while Catherine was able to identify all plants to genus and most to the species level.

We followed the quality assurance protocol set forth in the task description dated May 22, 2001 (PO \# 0B0368NTNA Change 1). Specifically we:

1. Recorded the presence of the following nine species in $2210 \mathrm{~m}$ x $10 \mathrm{~m}$ plots.

Table 1. Target Exotic Species

\begin{tabular}{|l|l|c|}
\hline Species & Scientific name & Code \\
\hline Canada Thistle & Cirsium arvense & CTH \\
\hline Cheatgrass & Bromus tectoram & CHE \\
\hline Common burdock & Arctium minus & BUR \\
\hline English Ivy & Hedera helix & IVY \\
\hline Leafy Spurge & Euphorbia esula & LSP \\
\hline Musk Thistle & Carduss nutans & MTH \\
\hline Russian-olive & Elaeagnus angustifolia & ROL \\
\hline Salt Cedar & Tamarix spp. & SCD \\
\hline Teasel & Dipsacus fullonum & TEA \\
\hline
\end{tabular}

2. Recorded the "legacy tree" visible from each MTDEQ plot. The tree species, (later normalized to the taxonomic affiliation) height, diameter at breast height (dbh), and distance from the stream were obtained 
based on a visual estimate and recorded using the following: DBH categories $(\mathbf{1}=<0.1 \mathrm{~m}, 2=0.1$ to 0.3 $\mathrm{m}, \mathbf{3}=0.3$ to $0.75 \mathrm{~m}, \mathbf{4}=0.75$ to $2.0 \mathrm{~m}, \mathbf{5}=>2 \mathrm{~m})$. Height Categories $(\mathbf{1}=<5 \mathrm{~m}, \mathbf{2}=5-15 \mathrm{~m}, \mathbf{3}=15-30$ $\mathrm{m}, \mathbf{4}=>30 \mathrm{~m})$.

Table 2. The taxonomic affiliation and codes used to describe legacy trees.

\begin{tabular}{|l|c|}
\hline SPECIES AFFILIATION & CODE \\
\hline Alder/Birch & ALD \\
\hline Ash & ASH \\
\hline Cedar/Cypress/Sequoia & CED \\
\hline Fir, Doug Fir, Hemlock & FIR \\
\hline Juniper & JUN \\
\hline Maple/Boxelder & MAP \\
\hline Pine & PIN \\
\hline Popular/Cottonwood & POP \\
\hline Spruce & SPR \\
\hline Sycamore & SYC \\
\hline Willow & WIL \\
\hline other broadleaf evergreen & UEV \\
\hline other conifer & UCO \\
\hline other deciduous & UDE \\
\hline
\end{tabular}

3. Recorded the presence of all visible plant species within $10 \mathrm{~m}$ on both sides of the stream in $100-\mathrm{m}$ increments along the stream reach. The number of transects completed per site ranged from 2 to 4 , depending upon difficulty and time spent completing tasks $1 \& 2$ and the distance and time required to arrive at the next work site.

\section{Data Management}

Field data gathered for steps 1 and 2, exotic species and legacy data, were entered into excel worksheets; each worksheet represents a sampled stream section. These worksheets are included as Appendix A in this report. Field data gathered for step 3, plant species list for $100 \mathrm{~m}$ increments, were entered into an Access database, exported to excel and summarized by site. These results are presented in Appendix B. Electronic copies of the field forms populated with field data and the summary data in Appendix B are copied to a CD ROM located on the inside of the back cover page of this report.

\section{RESULTS}

\section{Relocating Quality Assurance Sites}

The MTNHP completed six quality assurance sites in 2001. We relocated the plot center of each stream reach and the center of each plot. In one instance (Tenderfoot - headwaters WMTP99-0521), flagging was missing from a downstream plot; here we estimated plot center by splitting the distance between the next upstream and downstream plots. 


\section{Target Exotic Species Encountered}

Only one target species, Canada thistle (Cirsium arvense), was found. We encountered this species three times, once at Little Boulder Creek (WMTP-99-0633) and twice at South Fork Little Joe Creek (WMTP99-0608). In both cases, the thistle was a single vegetative stem (without flower or fruiting structures) growing in fresh sand/gravel bar deposits. It is possible the stem emerged following the original survey. The results of the target exotic species inventory are summarized in Table 3.

Table 3. Matrix table summarizing the number of plots the target alien species was recorded by site. The Stream ID along the upper row of the matrix identifies sites.

\begin{tabular}{|l|c|c|c|c|c|c|}
\hline SPECIES & $\begin{array}{c}\text { WMTP99- } \\
\mathbf{0 6 0 7}\end{array}$ & $\begin{array}{c}\text { WMTP-99 } \\
\mathbf{0 5 2 1}\end{array}$ & $\begin{array}{c}\text { WMTP-99 } \\
\mathbf{0 6 0 9}\end{array}$ & $\begin{array}{c}\text { WMTP-99 } \\
\mathbf{0 6 3 3}\end{array}$ & $\begin{array}{c}\text { WMTP-99 } \\
\mathbf{0 6 0 8}\end{array}$ & $\begin{array}{c}\text { WMTP-99 } \\
\mathbf{0 6 0 0}\end{array}$ \\
\hline Canada Thistle & 0 & 0 & 0 & 1 & 2 & 0 \\
\hline Cheatgrass & 0 & 0 & 0 & 0 & 0 & 0 \\
\hline Common burdock & 0 & 0 & 0 & 0 & 0 & 0 \\
\hline English Ivy & 0 & 0 & 0 & 0 & 0 & 0 \\
\hline Leafy Spurge & 0 & 0 & 0 & 0 & 0 & 0 \\
\hline Musk Thistle & 0 & 0 & 0 & 0 & 0 & 0 \\
\hline Russian-olive & 0 & 0 & 0 & 0 & 0 & 0 \\
\hline Salt Cedar & 0 & 0 & 0 & 0 & 0 & 0 \\
\hline Teasel & 0 & 0 & 0 & 0 & 0 & 0 \\
\hline
\end{tabular}

\section{Legacy Trees}

We recorded legacy trees from each MTDEQ plot. We followed the sampling protocol where the largest tree within the riparian zone (restricted to a distance of $50 \mathrm{~m}$ ) was recorded on both left and right bank. Observations were made from each plot to the next upstream plot and recorded in the plot from which the observation was made. Overall the legacy tree data was the hardest to ensure accuracy. For example, a stream could meander so that one legacy tree plot was within another - assuming the plot was at right angles with the stream direction. Another problem arises from the subjective decision of where the riparian zone ends, especially when dense vegetation obscures the understory indicators. Nevertheless, we have very high confidence in the tree species, or affinity and whether the tree was alive or dead. We have relatively high confidence in the tree height estimates since the variable is placed in a category. The diameter at breast height was at times obscured by dense vegetation; therefore we have less confidence in this value.

\section{Other Species including exotics not listed as targets}

We completed seventeen 100-m transects where we recorded all recognizable plant species within $10 \mathrm{~m}$ on either side of the stream. A minimum of two transects were completed at each site; these transects were numbered $5 \& 6$ where plot 5 was located in the 100-m stretch upstream from plot center and plot 6 was located in the 100-m stretch downstream from plot center. Most plant species were identified while standing in the stream center; in some cases, specimens were collected to inspect flowering parts. A few specimens were run through taxonomic key for verification.

We documented fifteen plant species known to be exotic in Montana. To be certain that we didn't overlook any exotic species, we queried an ACCESS database used at the MTNHP that originated from 
the USFS Region 1 office in Missoula, Montana in 1998. This database contains an 'Origin' field where $\mathrm{E}=$ exotic. We also queried our species list against the INVADER database (Rice, P.M. 2001) housed at Montana State University. This database is a good source for exotic and noxious species for Montana. These results concurred with the results obtained from the USFS R1 database with two exceptions: Smooth Brome (Bromus inermis) and Common mouse-ear chickweed (Cerastium fontanum) were not listed as exotic species. We doubled checked these species accounts on the NatureServe web site (2001) and found both species were listed as exotic in Montana. Finally, we obtained a recent Forest Service report titled 'Evaluating Risk to Native Plant Communities from Invasion of Selected Exotic Plant Species' (Mantas and Jones, 2001). This document is a report on a 2001 expert workshop that identified the potential invasiveness of exotic species into natural communities in Western Montana. A similar report for Eastern Montana will be available in 2001. The results of these inquiries are presented in Table 4.

Table 4. Exotic species documented along 100-m intervals.

\begin{tabular}{|l|c|c|c|}
\hline \multicolumn{1}{|c|}{ Species } & $\begin{array}{c}\text { USFS } \\
\text { R1 } \\
\text { exotics }\end{array}$ & $\begin{array}{c}\text { Invaders db } \\
\text { noxious in: }\end{array}$ & $\begin{array}{c}\text { USFS R1 } \\
\text { Invasive Risk }\end{array}$ \\
\hline Bromus inermis & $\mathrm{e}$ & $\mathrm{e}$ & \\
\hline Agrostis stolonifera & $\mathrm{e}$ & $\mathrm{e}$ & \\
\hline Centaurea maculosa & $\mathrm{e}$ & ID,MT,OR,WA,WY & IH,DL,CN \\
\hline Cerastium fontanum & $\mathrm{e}$ & $\mathrm{e}$ & \\
\hline Chrysanthemum leucanthemum & $\mathrm{e}$ & MT,WA,WY & \\
\hline Cirsium arvense & $\mathrm{e}$ & ID,MT,OR,WA,WY & CN,DL,DH \\
\hline Conium maculatum & $\mathrm{e}$ & ID,OR,WA & \\
\hline Dactylis glomerata & $\mathrm{e}$ & $\mathrm{e}$ & \\
\hline Medicago falcata & $\mathrm{e}$ & $\mathrm{e}$ & \\
\hline Phleum pratense & $\mathrm{e}$ & $\mathrm{e}$ & \\
\hline Poa palustris & $\mathrm{e}$ & $\mathrm{e}$ & \\
\hline Poa pratensis & $\mathrm{e}$ & $\mathrm{e}$ & \\
\hline Tanacetum vulgare & $\mathrm{e}$ & $\mathrm{MT}, \mathrm{WA}$ & $\mathrm{CN}, \mathrm{UU}, \mathrm{DL}, \mathrm{DH}$ \\
\hline Taraxacum officinale & $\mathrm{e}$ & $\mathrm{e}$ & \\
\hline
\end{tabular}

1 First code is the Susceptibility (C = Closed, $\mathrm{D}=$ Disturbance, $\mathrm{I}=$ Invasive, $\mathrm{U}=$ Unknown susceptibility); Second code is the Threat ( $\mathrm{N}=$ no threat, $\mathrm{L}=$ low threat, $\mathrm{H}=$ high threat, $\mathrm{U}=$ Unknown threat). Multiple values indicate the species susceptibility to invasion differs for different community types.

All other species (including alien) recorded along the 10 -m by $100-\mathrm{m}$ stream increments are presented in Appendix B.

\section{REFERENCES}

Mantas, M.; and J. Jones, 2001. Evaluating Risk to Native Plant Communities from Invasion of Selected Exotic Plant Species. A proposal for the Western Montana Planning Zone. Flathead National Forest, Montana. Unpublished Report available at the Montana Natural Heritage Program.

NatureServe, 2001. NatureServe Explorer: Online Encyclopedia of Life (http://www.natureserveexplorer.org/) Data accessed on November 13, 2001.

Rice, P.M. 2001. INVADERS Database System (http://invader.dbs.umt.edu). Division of Biological Sciences, University of Montana, Missoula, MT 59812-4824. Data accessed on November 13, 2001 


\section{ERRATUM $^{1}$}

\section{Appendix B. Species encountered along $100 \mathrm{~m}$ increments}

All species observed in 10-m by 100-m increments along the MTDEQ site. Cells show the number of times the species was recorded by site. The number of increments completed in each site is in parenthesis. Exotic species are shaded across the row.

\begin{tabular}{|c|c|c|c|c|c|c|}
\hline & WMTP99 & -WMTP99- & -WMTP99- & -WMTP99- & WMTP99- & -WMTP99- \\
\hline Species & $\begin{array}{c}521 \\
(4) \\
\end{array}$ & \begin{tabular}{|c|}
600 \\
$(2)$ \\
\end{tabular} & \begin{tabular}{|c|}
607 \\
$(3)$ \\
\end{tabular} & \begin{tabular}{|c|}
608 \\
$(2)$ \\
\end{tabular} & $\begin{array}{c}609 \\
(4) \\
\end{array}$ & \begin{tabular}{|c||}
633 \\
$(2)$ \\
\end{tabular} \\
\hline Abies grandis & 0 & 1 & 3 & 2 & 0 & 0 \\
\hline Abies lasiocarpa & 2 & 0 & 0 & 0 & 4 & 0 \\
\hline Acer glabrum & 0 & 1 & 1 & 0 & 0 & 0 \\
\hline Achillea millefolium & 4 & 1 & 1 & 0 & 0 & 1 \\
\hline Actaea rubra & 0 & 0 & 0 & 2 & 2 & 2 \\
\hline Agoseris glauca & 3 & 0 & 0 & 0 & 0 & 0 \\
\hline Agrostis scabra & 4 & 0 & 0 & 0 & 0 & 0 \\
\hline Agrostis spp. & 4 & 2 & 3 & 2 & 0 & 0 \\
\hline Agrostis stolonifera & 0 & 1 & 0 & 1 & 0 & 0 \\
\hline Allium spp. & 2 & 0 & 0 & 0 & 0 & 0 \\
\hline Alnus incana & 0 & 0 & 0 & 0 & 4 & 0 \\
\hline Alnus sinuata & 0 & 2 & 3 & 2 & 0 & 0 \\
\hline Alnus spp. & 0 & 0 & 0 & 0 & 0 & 2 \\
\hline Alopecurus spp. & 0 & 0 & 1 & 0 & 0 & 0 \\
\hline Amelanchier alnifolia & 0 & 1 & 3 & 1 & 0 & 0 \\
\hline Anaphalis margaritacea & 0 & 2 & 3 & 2 & 0 & 0 \\
\hline Angelica arguta & 2 & 0 & 0 & 0 & 4 & 0 \\
\hline Angelica dawsonii & 0 & 0 & 3 & 0 & 0 & 0 \\
\hline Angelica spp. & 0 & 2 & 0 & 2 & 0 & 2 \\
\hline Antennaria racemosa & 0 & 0 & 0 & 0 & 1 & 0 \\
\hline Antennaria spp. & 4 & 1 & 0 & 0 & 0 & 2 \\
\hline Aralia nudicaulis & 0 & 1 & 1 & 0 & 0 & 0 \\
\hline Arctostaphylos uva-ursi & 0 & 0 & 0 & 0 & 3 & 0 \\
\hline Arnica cordifolia & 0 & 0 & 0 & 0 & 4 & 0 \\
\hline Arnica spp. & 0 & 0 & 0 & 0 & 0 & 2 \\
\hline Aster conspicuus & 0 & 0 & 0 & 0 & 3 & 0 \\
\hline Aster engelmannii & 0 & 0 & 0 & 0 & 4 & 0 \\
\hline Aster foliaceus & 4 & 0 & 0 & 0 & 4 & 0 \\
\hline Aster laevis & 0 & 0 & 0 & 0 & 4 & 0 \\
\hline Aster modestus & 0 & 0 & 0 & 0 & 4 & 0 \\
\hline Aster occidentalis & 0 & 0 & 0 & 0 & 4 & 0 \\
\hline Astragalus spp. & 1 & 0 & 0 & 0 & 0 & 2 \\
\hline Berberis repens & 0 & 0 & 0 & 0 & 3 & 0 \\
\hline Betula occidentalis & 0 & 1 & 0 & 0 & 0 & 0 \\
\hline Brickellia grandiflora & 0 & 0 & 0 & 2 & 0 & 0 \\
\hline
\end{tabular}

\footnotetext{
${ }^{1}$ The following changes have been made. WMTP99-608 - Chrysanthemum leucanthemum, Dactylis glomerata and
} Parnassia spp. from 3 to 2. WMTP99-600 and 633 - Salix spp. from 3 to 2. 


\begin{tabular}{|c|c|c|c|c|c|c|}
\hline & WMTP99 & -WMTP99- & -WMTP99- & WMTP99-I & WMTP99- & -WMTP99- \\
\hline Species & $\begin{array}{c}521 \\
(4)\end{array}$ & $\begin{array}{c}600 \\
(2)\end{array}$ & \begin{tabular}{|c|}
607 \\
$(3)$
\end{tabular} & \begin{tabular}{|c|}
608 \\
$(2)$
\end{tabular} & $\begin{array}{c}609 \\
(4)\end{array}$ & \begin{tabular}{|c|}
633 \\
$(2)$
\end{tabular} \\
\hline Bromus carinatus & 4 & 0 & 0 & 0 & 0 & 0 \\
\hline Bromus ciliatus & 2 & 0 & 2 & 0 & 4 & 0 \\
\hline Bromus inermis & 0 & 0 & 1 & 2 & 0 & 0 \\
\hline Bromus spp. & 2 & 0 & 0 & 1 & 0 & 1 \\
\hline Bromus vulgaris & 0 & 0 & 0 & 0 & 4 & 0 \\
\hline Calamagrostis canadensis & 4 & 0 & 0 & 0 & 4 & 0 \\
\hline Calamagrostis rubescens & 0 & 0 & 0 & 0 & 3 & 0 \\
\hline Calamagrostis spp. & 0 & 2 & 2 & 0 & 0 & 2 \\
\hline Calochortus spp. & 3 & 0 & 0 & 0 & 0 & 0 \\
\hline Campanula rotundifolia & 1 & 0 & 2 & 0 & 0 & 2 \\
\hline Carex geyeri & 0 & 0 & 0 & 0 & 4 & 1 \\
\hline Carex microptera & 4 & 0 & 0 & 0 & 0 & 0 \\
\hline Carex scopulorum & 4 & 0 & 0 & 0 & 0 & 0 \\
\hline Carex spp. & 0 & 1 & 1 & 1 & 0 & 0 \\
\hline Castilleja linariifolia & 0 & 0 & 1 & 0 & 0 & 0 \\
\hline Centaurea maculosa & 0 & 0 & 1 & 1 & 0 & 0 \\
\hline Cerastium fontanum & 0 & 2 & 0 & 2 & 0 & 0 \\
\hline Chimaphila umbellata & 0 & 0 & 0 & 0 & 2 & 0 \\
\hline Chrysanthemum leucanthemum & 0 & 0 & 1 & 2 & 0 & 0 \\
\hline Circaea alpina & 0 & 0 & 0 & 2 & 0 & 0 \\
\hline Cirsium arvense & 0 & 0 & 0 & 1 & 0 & 1 \\
\hline Cirsium scariosum & 3 & 0 & 0 & 0 & 0 & 0 \\
\hline Cirsium spp. & 0 & 0 & 2 & 0 & 0 & 0 \\
\hline Clematis columbiana & 0 & 1 & 0 & 0 & 0 & 0 \\
\hline Clintonia uniflora & 0 & 1 & 1 & 2 & 0 & 0 \\
\hline Collomia spp. & 3 & 0 & 0 & 0 & 0 & 0 \\
\hline Conium maculatum & 0 & 0 & 0 & 1 & 0 & 0 \\
\hline Coptis occidentalis & 0 & 0 & 0 & 2 & 0 & 0 \\
\hline Cornus canadensis & 0 & 2 & 1 & 0 & 0 & 0 \\
\hline Cornus sericea & 0 & 2 & 3 & 2 & 4 & 2 \\
\hline Crepis runcinata & 0 & 0 & 1 & 0 & 0 & 0 \\
\hline Crepis spp. & 0 & 0 & 0 & 0 & 0 & 2 \\
\hline Dactylis glomerata & 0 & 0 & 1 & 2 & 0 & 0 \\
\hline Danthonia californica & 4 & 0 & 0 & 0 & 0 & 0 \\
\hline Danthonia spp. & 0 & 0 & 0 & 0 & 0 & 1 \\
\hline Deschampsia cespitosa & 4 & 0 & 0 & 0 & 0 & 0 \\
\hline Disporum spp. & 0 & 2 & 1 & 0 & 0 & 0 \\
\hline Dodecatheon spp. & 2 & 0 & 0 & 0 & 0 & 0 \\
\hline Elymus glaucus & 0 & 2 & 3 & 0 & 4 & 0 \\
\hline Elymus trachycaulus & 2 & 0 & 0 & 0 & 0 & 0 \\
\hline Epilobium angustifolium & 3 & 2 & 0 & 2 & 4 & 2 \\
\hline Epilobium ciliatum & 4 & 2 & 3 & 0 & 0 & 2 \\
\hline Equisetum arvense & 1 & 2 & 3 & 0 & 0 & 2 \\
\hline Erigeron foliosus & 0 & 2 & 3 & 0 & 0 & 0 \\
\hline
\end{tabular}




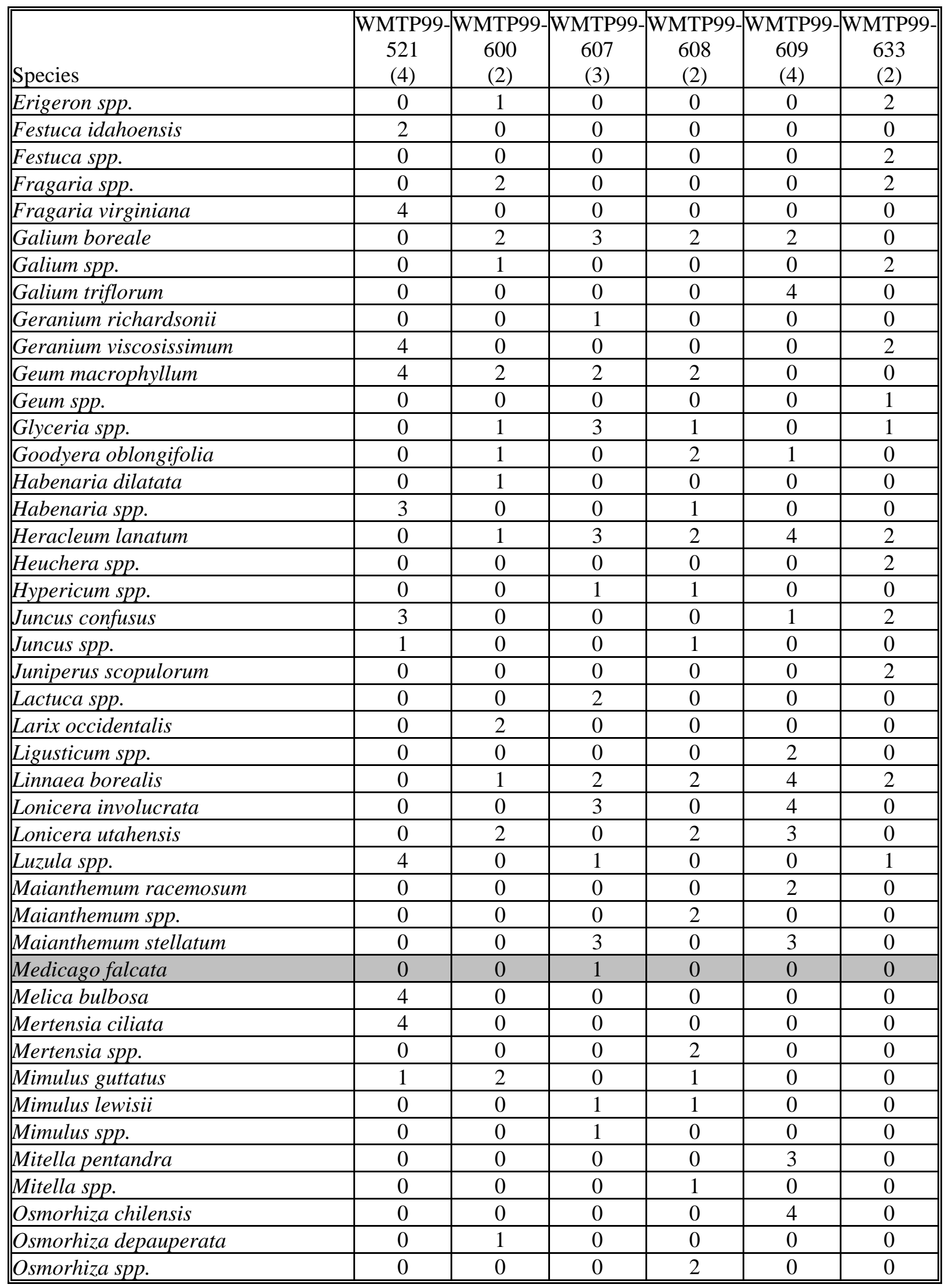




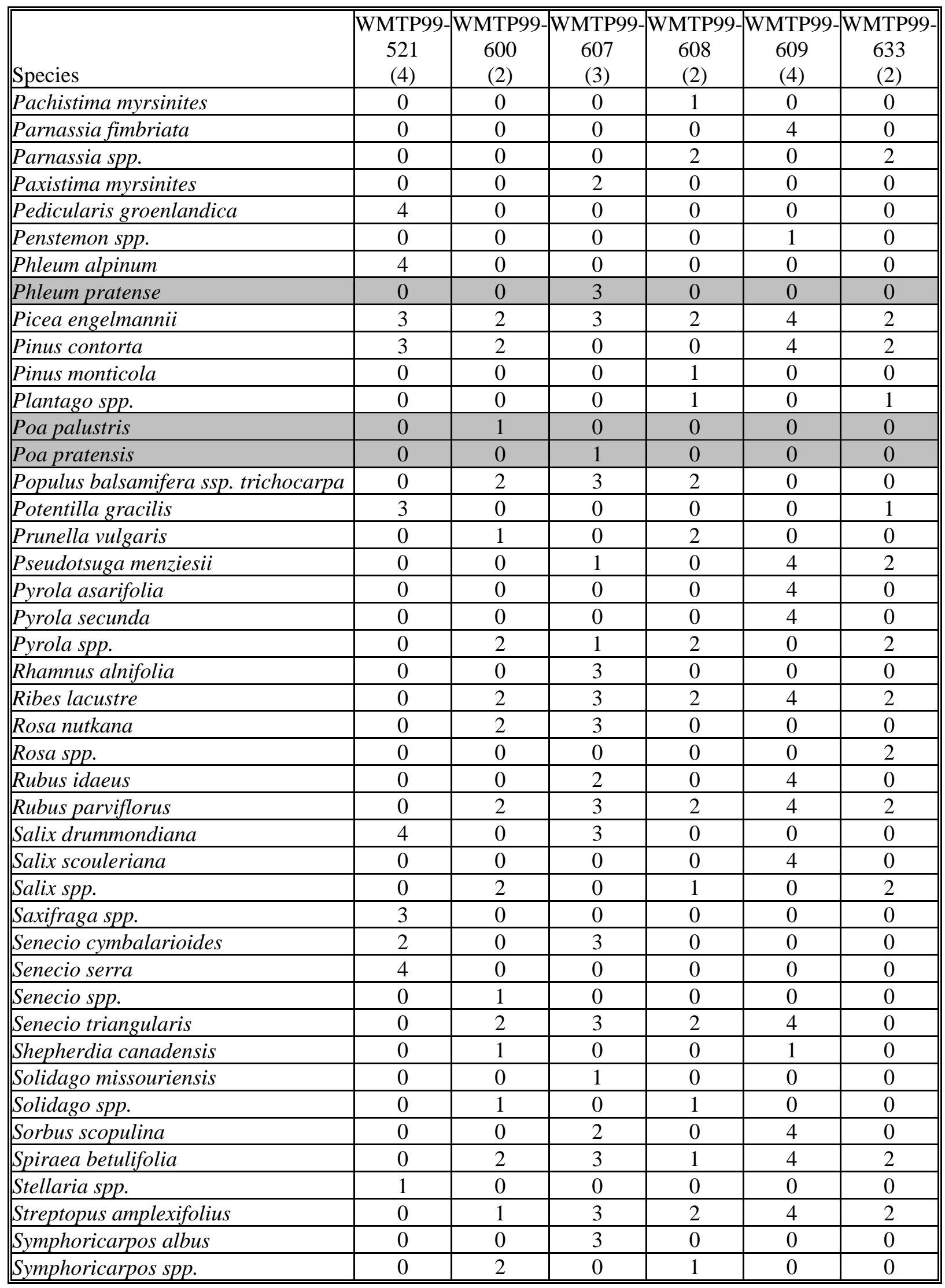




\begin{tabular}{||l|c|c|c|c|c|c||}
\hline \hline & WMTP99-WMTP99- & WMTP99- & WMTP99-WMTP99-WMTP99- \\
Species & $\begin{array}{l}\text { WM } \\
(4)\end{array}$ & 600 & 607 & 608 & 609 & 633 \\
$(2)$ & $(3)$ & $(2)$ & $(4)$ & $(2)$ \\
\hline Tanacetum vulgare & 0 & 0 & 0 & 2 & 0 & 0 \\
\hline Taraxacum officinale & 4 & 1 & 2 & 1 & 0 & 1 \\
\hline Taxus brevifolia & 0 & 0 & 2 & 0 & 0 & 0 \\
\hline Thalictrum occidentale & 0 & 0 & 3 & 0 & 4 & 0 \\
\hline Thalictrum spp. & 4 & 2 & 0 & 0 & 0 & 2 \\
\hline Thelypodium spp. & 1 & 0 & 0 & 0 & 0 & 0 \\
\hline Thuja plicata & 0 & 0 & 0 & 2 & 0 & 0 \\
\hline Tiarella trifoliata & 0 & 0 & 1 & 2 & 0 & 0 \\
\hline Trifolium spp. & 4 & 0 & 0 & 1 & 0 & 2 \\
\hline Trillium ovatum & 0 & 1 & 0 & 2 & 0 & 0 \\
\hline Trisetum spp. & 0 & 0 & 0 & 0 & 0 & 1 \\
\hline Urtica dioica & 0 & 0 & 1 & 0 & 0 & 0 \\
\hline Vaccinium membranaceum & 0 & 0 & 2 & 0 & 4 & 0 \\
\hline Vaccinium myrtillus & 0 & 0 & 0 & 0 & 4 & 0 \\
\hline Vaccinium scoparium & 3 & 0 & 0 & 0 & 2 & 1 \\
\hline Vaccinium spp. & 1 & 0 & 0 & 2 & 0 & 0 \\
\hline Veronica spp. & 0 & 0 & 2 & 0 & 0 & 0 \\
\hline Viola spp. & 3 & 1 & 1 & 2 & 0 & 1 \\
\hline
\end{tabular}

